\title{
Makara Journal of Technology
}

$12-3-2021$

\section{Identification of Thermophilic Bacteria from Tirta Lebak Buana Hot Spring in Serang, Banten, Indonesia}

\author{
Kenny Lischer \\ Bioprocess Engineering, Department of Chemical Engineering, Faculty of Engineering, Universitas \\ Indonesia, Depok 16424, Indonesia, lischer.kenny@ui.ac.id
}

Follow this and additional works at: https://scholarhub.ui.ac.id/mjt

\section{Recommended Citation}

Lischer, Kenny (2021) "Identification of Thermophilic Bacteria from Tirta Lebak Buana Hot Spring in Serang, Banten, Indonesia," Makara Journal of Technology: Vol. 25 : No. 3 , Article 6.

DOI: $10.7454 / \mathrm{mst} . v 25 i 3.3993$

Available at: https://scholarhub.ui.ac.id/mjt/vol25/iss3/6

This Article is brought to you for free and open access by the Universitas Indonesia at UI Scholars Hub. It has been accepted for inclusion in Makara Journal of Technology by an authorized editor of UI Scholars Hub. 


\title{
Identification of Thermophilic Bacteria from Tirta Lebak Buana Hot Spring in Serang, Banten, Indonesia
}

\author{
Kenny Lischer* \\ Bioprocess Engineering, Department of Chemical Engineering, Faculty of Engineering, Universitas Indonesia, \\ Depok 16424, Indonesia \\ "E-mail: lischer.kenny@ui.ac.id
}

\begin{abstract}
Since Taq polymerase was first explored and identified from thermophilic bacteria, these bacteria have become wellknown sources of thermostable enzymes. New thermophilic bacteria have been investigated to broaden biodiversity and translation research. Studies have shown interests in Indonesia because of thermophilic bacteria found in hot springs. This country is traversed by the ring of fire and has more than 70 volcanoes, resulting in the wide distribution of hot springs across the country. Although many reports have been performed, studies have yet to explore thermophilic bacteria in Tirta Lebak Buana hot springs, Java Island, Indonesia. This research was the first to examine thermophilic bacteria in Tirta Lebak Buana hot spring. Two samples from two different sampling sites were obtained and analyzed through 16srRNA analysis (sampling sites A and B). Measurements indicated that the temperature $\left(50^{\circ} \mathrm{C}\right)$ in sampling site A was higher than that in sampling site $\mathrm{B}\left(40{ }^{\circ} \mathrm{C}\right)$, but they had similar $\mathrm{pH}$ (7.0). Polymerase chain reaction (PCR) showed that the 16srRNA of the specimen was around $1465 \mathrm{bp}$. The analysis of the 16srRNA sequence revealed that the obtained bacteria have a similar sequence and close relationship with Bacillus subtilis subsp. stercoris strain N12.
\end{abstract}

\begin{abstract}
Abstrak
Identifikasi Bakteri Termofilik Berasal dari Pemandian Air Panas Tirta Lebak Buana, Serang, Banten, Indonesia. Sejak eksplorasi Taq polimerase dari bakteri termofilik, bakteri tersebut menjadi sumber dari enzim yang termostabil. Sebagai hasilnya, banyak sekali eksplorasi untuk mencari bakteri termofilik baru untuk memperluas biodiversitas dan riset aplikasi. Indonesia termasuk salah satu negara yang dikelilingi oleh cincin api sehingga memiliki lebih dari 70 gunung api yang tersebar di seluruh penjuru negeri. Oleh karena itu, Indonesia menjadi negara untuk dijadikan tempat mengkesplorai bakteri termofilik dari pemandian air panas. Meskipun telah banyak laporan yang dihasilkan, belum ada laporan mengenai eksplorasi bakteri termofilik yang berasal dari pemandian Tirta Lebak Buana, Pulau Jawa, Indonesia. Penelitian ini merupakan studi pertama yang dilakukan di tempat tersebut. Dalam penelitian ini, dua sampel didapatkan dari tempat yang berbeda dan dianalisa dengan menggunakan analisis 16srRNA. Dari perhitungan, didapatkan bahwa tempat sumber sampel A memiliki suhu lebih tinggi $\left(50^{\circ} \mathrm{C}\right)$ dibanding tempat sumber sampel B $\left(40{ }^{\circ} \mathrm{C}\right)$. Hasil analisis 16 srRNA dengan PCR berhasil dilakukan dengan ukuran sebesar 1465 bp. Analisis dari sekuens 16srRNA menghasilkan bahwa bakteria yang dihasilkan memiliki kemiripan dengan Bacillus subtilis subsp. stercoris strain N12.
\end{abstract}

Keywords: hot spring, moderate thermophile, thermophilic bacteria, tirta lebak buana, 16srRNA

\section{Introduction}

Initially discovered in 1953, thermophilic bacteria can remain alive at high temperatures (more than $40{ }^{\circ} \mathrm{C}-90$ ${ }^{\circ} \mathrm{C}$ ) [1]. Since the exploration of $\mathrm{Taq}$ polymerase from Thermus aquaticus, thermophilic bacteria have led to the global revolution of biology [2-5]. They have become well-known microorganisms for their ability to produce thermostable enzymes that can be used for industrial applications [6]. However, the biodiversity of thermophilic bacteria has not yet been fully explored.

Indonesia has more than 70 volcanoes distributed in Sumatra, Java, Bali, Kalimantan, Sulawesi, and Papua [7], and a total of 256 hot springs are found in Indonesia [8]. Interestingly, hot springs are known as the habitat of thermophilic bacteria [1]. Therefore, thermophilic bacteria from hot springs in Indonesia are interesting 
organisms to be explored. Microbes in hot springs around Indonesia were initially explored in 1991. Approximately eight different species were identified from nine selected hot springs, namely, Toya Bungkah, Sikidang, Candradimuka, Sileri, Domas, Badak, Djarian, Ciater, and Gunung Gede, respectively [9]. Since then, efforts devoted to biodiversity exploration in hot springs have significantly increased.

At least three methods, namely, culture and morphological approach, 16srRNA, and whole-genome sequencing, can be applied to investigate microbial diversity in hot springs. Culture and morphological approaches are considered the easiest methods to identify microbes. These methods usually involve strain staining and morphological characterization [10-13]. However, these methods are limited by the small number of specimens to be identified [14]. With whole-genome sequencing, bacteria can be identified in detail from a cellular level to a DNA level. This method can also be utilized to explore all functional genes and improve the chance to determining newly discovered species [14]. Although the cost of whole-genome sequencing has decreased, it is still considerably high in developing countries. Another identification technique at the DNA level is 16srRNA analysis. 16srRNA is a gene that can be used for bacterial fingerprinting $[15,16]$. This method is considerably cheap because PCR is the only technique performed to target and sequence a single gene. As a result, 16srRNA becomes a commonly used method for the exploration of thermophilic bacteria, as demonstrated in hot springs in Prataan (Paenibacillus sp.), Cisolok (Paenibacillus cisolokensis), and Tutung (Brevibacillus borstelensis and Paenobacillus sp.) [17-19].

Indonesia has numerous microbiologically explored hot springs $[9,18,20,21]$. Although extensive research has been conducted, studies have yet to be performed to explore thermophiles in Tirta Lebak Buana hot springs. Therefore, this research aimed to isolate and identify thermophilic bacteria in Tirta Lebak Buana through 16srRNA analysis.

\section{Methods}

Sample collection and characterization. Water from two sites (A and B) in Tirta Lebak Buana Hotsprings in Serang, Banten (6³2'55.2" S 106 $23^{\prime} 58.0^{\prime \prime}$ E) was collected in vacuum-insulated water bottles in October 2019. It was then analyzed in terms of temperature, $\mathrm{pH}$, and sulfur content. The samples were transported at room temperature and stored at $-20{ }^{\circ} \mathrm{C}$. They were cultured in plates containing $1.6 \%$ peptone, $0.8 \%$ yeast extract, $0.6 \%$ sodium chloride, $2 \mathrm{~g} / \mathrm{L} \mathrm{MgSO}_{4}$, and $1.6 \%$ gellan gum (Thermofischer, USA) and incubated at 50 ${ }^{\circ} \mathrm{C}$ and $40{ }^{\circ} \mathrm{C}$.
Species identification. The obtained colonies were cultured in a Luria-Bertani medium and incubated at $37{ }^{\circ} \mathrm{C}$. Then, genomic DNA was extracted by using a

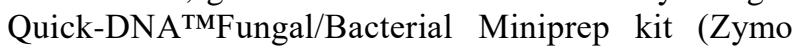
Research, D6005, USA). Polymerase chain reaction (PCR) was performed to the target 16srRNA by using the following forward and reverse primers, respectively: 5'-AGAGTTTGATCCTGGCTCAG-3') and 5'- CGGTTACCTTGTTACGA CTT-3'). During PCR, Taq polymerase and buffer (Bioneer, Korea) were also used at $92{ }^{\circ} \mathrm{C}$ for $5 \mathrm{~min}, 60{ }^{\circ} \mathrm{C}$ for $0.5 \mathrm{~min}$, and $72{ }^{\circ} \mathrm{C}$ for $1 \mathrm{~min}$ for 32 cycles followed by a final elongation at $72{ }^{\circ} \mathrm{C}$ for $5 \mathrm{~min}[22,23]$. The PCR results were analyzed through gel electrophoresis.

Phylogenetic tree and multiple alignment sequence analysis. Bidirectional sequencing was conducted to identify the 16srRNA sequence. The obtained sequenced was then used to analyze phylogenetic trees via BLAST. Multiple alignment sequence comparison with several known bacteria was performed with Clustal Omega.

\section{Result and Discussion}

Sampling location. Numerous hot springs are distributed in various locations in Indonesia. One of them is Tirta Lebak Buana hot spring, where thermophilic bacteria have yet to be explored. In Figure 1a, Tirta Lebak Buana hot spring is located in Banten province, Java Island, Indonesia $\left(6^{\circ} 32^{\prime} 55.2^{\prime \prime} \mathrm{S}\right.$ and $\left.106^{\circ} 23^{\prime} 58.0^{\prime \prime} \mathrm{E}\right)$. The location is less than $100 \mathrm{~km}$ from Krakatau. Water was collected from two different sampling sites for bacterial isolation. The main pond where the heat of hot spring is generated was set as sampling site A (Figure 1b). The part of the hot spring where people take a bath was assigned as sampling site $\mathrm{B}$ (Figure $1 \mathrm{~b}$ ). Both hot springs have neutral $\mathrm{pH}$ and no sign of sulfur odor (Table 1). They differ in temperature, i.e., the temperature in site $\mathrm{A}\left(50{ }^{\circ} \mathrm{C}\right)$ is higher than that in site $\mathrm{B}\left(40{ }^{\circ} \mathrm{C}\right)$. This temperature indicates that thermophilic bacteria may be thermophiles or moderately thermophiles.

PCR of 16srRNA. The thermophilic bacteria that can be obtained from this hot spring are unknown. In this study, water obtained from both sampling sites was cultured. The results revealed white colonies in the culture (Table 1). The obtained culture was then analyzed by using 16srRNA methods. In Figure 2, the size of the PCR band from sites A and B was around $1465 \mathrm{bp}$. This result showed that the 16srRNA of the thermophilic bacterial cultures was successfully amplified. The size of the band was considerably in the correct position because of the forward primer $27 \mathrm{~F}$ and the reverse primer $1492 \mathrm{R}$; this result indicated that it could amplify 16srRNA from sequence number 27 to $1492[22,23]$. 
(a)

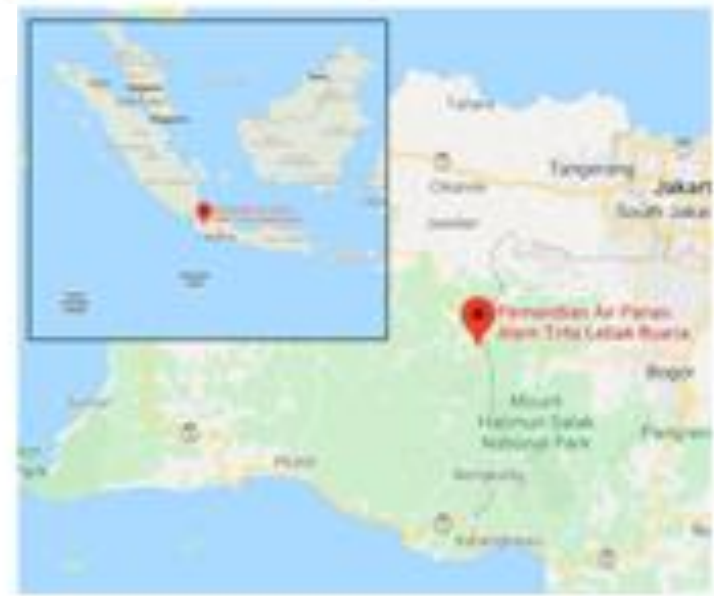

(b)

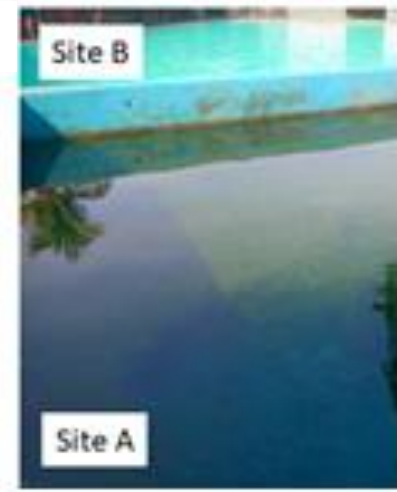

Figure 1. Sampling Location. (a) Map Location of Tirta Lebak Buana Hot Spring. (b) Sampling Sites A and $B$

16srRNA sequence analysis. The obtained 16srRNA was sequence from the PCR bands from sites A and B to gather further information about the species. The sequence was analyzed through BLAST application to find information regarding closely related bacteria. The result revealed that the samples from sites A and B had the closest relationship with Bacillus subtilis subsp. stercoris strain N12 (Figure 3). Multiple alignment sequencing was performed to further confirm the relationship of obtained bacteria with B. subtilis subsp. strain N12. In Figure 4, the samples from sites A and B have identical 16srRNA sequence. They also have a similar 16srRNA sequence to that of B. subtilis subsp. strain N12 (99\% similarity). Neither the sequence of Escherichia coli nor the sequence of Geobacillus thermoleovorans is similar to both samples. Therefore, both samples may be $B$. subtilis subsp. stercoris strain N12. This strain is characterized as moderate thermophilic bacteria or facultative thermophilic bacteria because they can live actively at high temperatures but below $40{ }^{\circ} \mathrm{C}$ [24]. However, moderate thermophiles have optimal growth temperature between $60{ }^{\circ} \mathrm{C}$ and $80{ }^{\circ} \mathrm{C}$ [25]. The only discovery that has been made is its identification in a food-waste bioreactor
[24]. Interestingly, it can also be found in nature, specifically in Tirta Lebak Buana hot spring. Future studies should be performed to identify the bacterial strain in detail via whole-genome sequencing. Various moderate thermophiles have many thermostable enzymes, such as SpCas9, lipase, cellulase, protease, and esterase [26-28]. Therefore, thermostable enzymes from B. subtilis subsp. stercoris strain N12 should be elucidated in future research.

Table 1. Sampling Site Characteristics

\begin{tabular}{c|c|c|c|c|}
\hline $\begin{array}{c}\text { Sampling } \\
\text { location }\end{array}$ & \multicolumn{1}{c}{$\mathrm{T}\left({ }^{\circ} \mathrm{C}\right)$} & $\mathrm{pH}$ & Sulfur & \multicolumn{1}{c}{$\begin{array}{c}\text { Colony } \\
\text { Color }\end{array}$} \\
\hline Site A & 50 & 7.0 & - & White \\
Site O & 40 & 7.0 & - & White \\
\hline
\end{tabular}

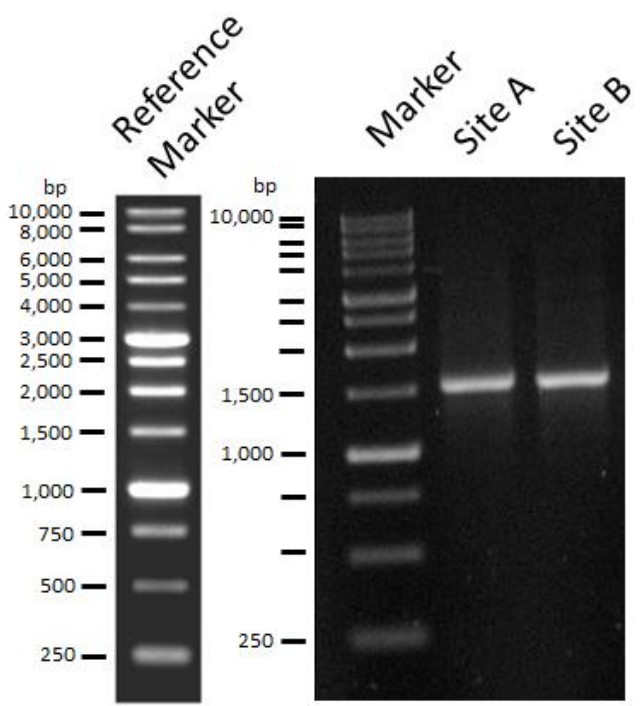

Figure 2. PCR Amplification of 16srRNA of the Samples from Sites A and B

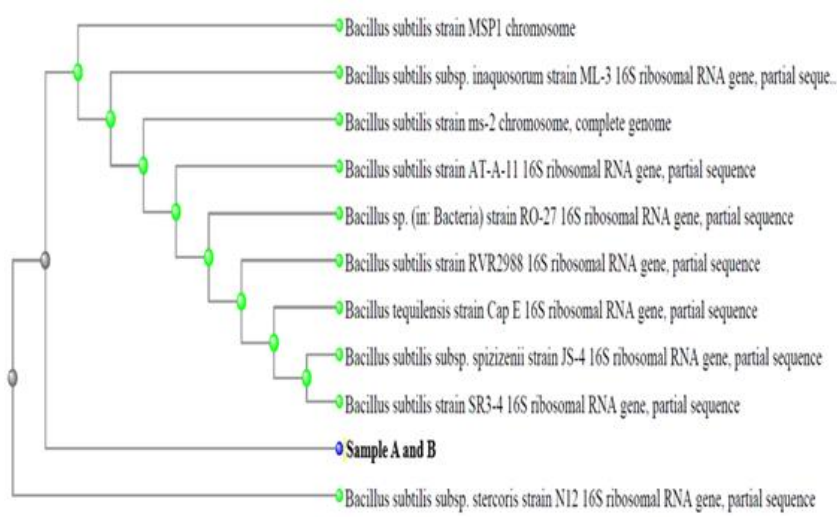

Figure 3. Phylogenetic Trees of Samples from Sites A and B 


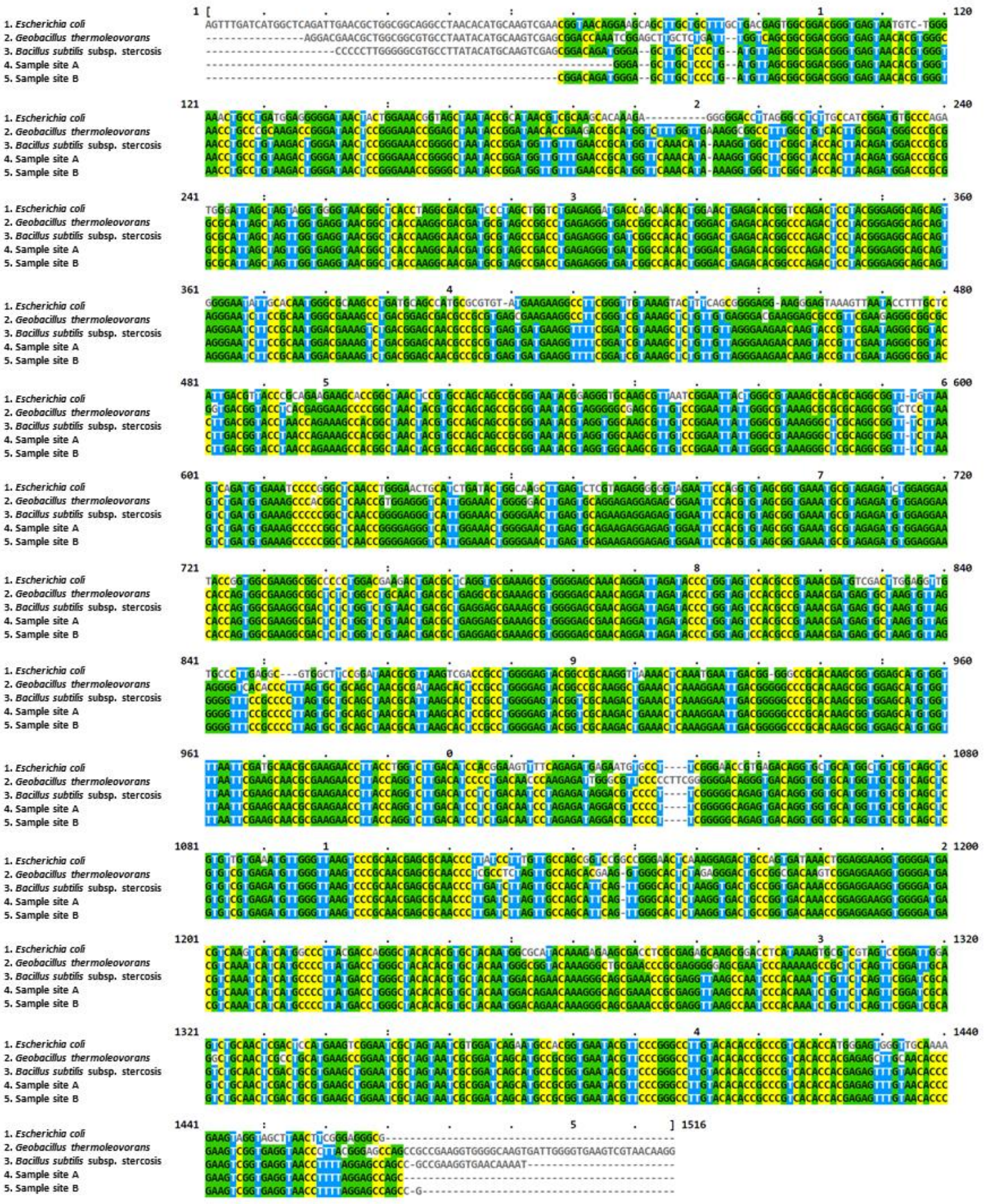

Figure 4. Multiple Sequence Alignment Comparison of the Samples from Sites A and B with Several Bacterial Species

\section{Conclusions}

This study is the first to isolate thermophilic bacteria from Tirta Lebak Buana hot spring. The obtained bacterial culture may be a moderate thermophile, $B$. subtilis subsp. stercoris strain N12. This promising result can be used for further studies related to its morphology, biological significance, and thermostable enzymes for industrial purposes. This study provides opportunities for future research, especially on $B$. subtilis subsp. stercoris strain $\mathrm{N} 12$, which should be further explored. 


\section{Acknowledgments}

KL performed the research, analyzed the data, and wrote the article. We would like to thank the Department of Chemical Engineering for the publication support.

\section{References}

[1] C.L. Marsh, D.H. Larsen, J. Bacteriol. 65/2 (1953) 193.

[2] A. Chien, D.B. Edgar, J.M. Trela, J. Bacteriol. 127/3 (1976) 1550.

[3] P. Hugenholtz, C. Pitulle, K.L. Hershberger, N.R. Pace, J. Bacteriol. 180/2 (1998) 366.

[4] K. Mori, H. Kim, T. Kakegawa, S. Hanada, Extremophiles. 7 (2003) 283.

[5] R.T. Papke, N.B. Ramsing, M.M. Bateson, D.M. Ward, Environ. Microbiol. 5/8 (2003) 650.

[6] B.L. Zamost, H.K. Nielsen, R.L. Starnes, J. Ind. Microbiol. 8 (1991) 71.

[7] P. Manalu, Geothermics. 17/3 (1988) 415.

[8] S. Darma, S. Harsoprayitno, B. Setiawan, A. WSoedibjo, N. Ganefianto, J. Stimac, Geo. Ene. Up. 25 (2010) 29.

[9] G. Huber, R. Huber, B.E. Jones, G. Lauerer, A. Neuner, A. Segerer, K.O. Stetter, E.T. Degens, Syst. Appl. Microbiol. 14/4 (1991) 397.

[10] A.P. Kusumadjaja, T. Budiati, N.N.T. Puspaningsih, S. Sajidan, Ind. J. Chem. 9/3 (2010) 470.

[11] Y. Harnentis, Y. Marlida, M. Rizal, K. Endo Mahata, Pak. J. Nutr. 12/4 (2013) 360.

[12] I. Hafsan, I. Irwan, L. Agustina, A. Natsir, A. Ahmad, Res. J. 5/9 (2017) 16.

[13] S. Ifandi, M. Alwi, Biosaintifika J. Biol. Biol. Ed. 10/2 (2018) 291.

[14] M. Land, L. Hauser, S.-R. Jun, I. Nookaew, M.R. Leuze, T.-H. Ahn, T. Karpinets, O. Lund, G. Kora,
T. Wassenaar, S. Poudel, D.W. Ussery, Funct. Integr. Genom. 15/2 (2015) 141.

[15] R. Huber, P. Rossnagel, C.R. Woese, R. Rachel, T.A. Langworthy, K.O. Stetter, Syst. Appl. Microbiol. 19/1 (1996) 40.

[16] D.M. Ward, M.J. Ferris, S.C. Nold, M.M. Bateson, Microbiol. Mol. Biol. Rev. 62/4 (1998) 1353.

[17] R. Chrisnasari, S. Yasaputera, P. Christianto, V.I. Santoso, T. Pantjajani, J. Math. Fundam. Sci. 48/2 (2016) 149.

[18] A. Yokota, F. Ningsih, D.G. Nurlaili, Y. Sakai, S. Yabe, A. Oetari, I. Santoso, W. Sjamsuridzal, Int. J. Syst. Evol. Microbiol. 66/8 (2016) 3088.

[19] S. Arzita, A. Agustien, Y. Rilda, J. Pure Appl. Microbiol. 11/4 (2017) 1789.

[20] F. Ningsih, A. Yokota, Y. Sakai, K. Nanatani, S. Yabe, A. Oetari, W. Sjamsuridzal, Int. J. Syst. Evol. Microbiol. 69/10 (2019) 3080.

[21] S.-J. Lee, Y.-J. Lee, N. Ryu, S. Park, H. Jeong, S.J. Lee, B.-C. Kim, D.-W. Lee, H.-S. Lee, J. Bacteriol. 194/23 (2012) 6684.

[22] P.A. Eden, T.M. Schmidt, R.P. Blakemore, N.R. Pace, Int. J. Syst. Bacteriol. 41/2 (1991) 324.

[23] H. Jiang, H. Dong, G. Zhang, B. Yu, L.R. Chapman, M.W. Fields, Appl. Environ. Microbiol. 72/6 (2006) 3832.

[24] J. Adelskov, B.K.C. Patel, 3 Biotech 6/1 (2016) 1.

[25] C.M.M.C. Andrade, N. Pereira, G. Antranikian, Rev. Microbiol. 30/4 (1999) 287.

[26] I. Mougiakos, E.F. Bosma, K. Weenink, E. Vossen, K. Goijvaerts, J. Van Der Oost, R. Van Kranenburg, ACS Synth. Biol. 6/5 (2017) 849.

[27] B.T. Mohammad, H.I. Al Daghistani, A. Jaouani, S. Abdel-Latif, C. Kennes, Int. J. Microbiol. 2017 (2017) 1.

[28] A. Kademi, N. Ait-Abdelkader, L. Fakhreddine, J. Baratti, Appl. Microbiol. Biotechnol. 54/2 (2000) 173. 